\title{
Radiative forcing by forest and subsequent feedbacks in the early Eocene climate
}

\section{U. Port ${ }^{1}$, M. Claussen ${ }^{1,2}$, and V. Brovkin ${ }^{1}$}

${ }^{1}$ Max Planck Institute for Meteorology, Hamburg 20146, Germany

${ }^{2}$ Meteorological Institute, University of Hamburg, Hamburg 20146, Germany

Received: 2 March 2015 - Accepted: 13 March 2015 - Published: 30 March 2015

Correspondence to: U. Port (ulrike.port@mpimet.mpg.de)

Published by Copernicus Publications on behalf of the European Geosciences Union.

\section{Radiative forcing by forest and subsequent feedbacks in the early Eocene climate \\ U. Port et al.}

\section{Title Page}

14 4

\section{Full Screen / Esc}

Printer-friendly Version

Interactive Discussion 


\section{Abstract}

Using the Max Planck Institute for Meteorology Earth System Model, we investigate the forcing of forests and the feedback triggered by forests in the pre-industrial climate and in the early Eocene climate (about 54 to 52 million years ago). Other than the 5 interglacial, pre-industrial climate, the early Eocene climate was characterised by high temperatures which led to almost ice-free poles. We compare simulations in which all continents are covered either by dense forest or by bare soil. To isolate the effect of soil albedo, we choose either bright soils or dark soils, respectively. Considering bright soil, forests warm in both, the early Eocene climate and the current climate, but the warming differs due to differences in climate feedbacks. The lapse-rate and watervapour feedback is stronger in early Eocene climate than in current climate, but strong and negative cloud feedbacks and cloud masking in the early Eocene climate outweigh the stronger positive lapse-rate and water-vapour feedback. In the sum, global mean warming is weaker in the early Eocene climate. Sea-ice related feedbacks are weak in the almost ice-free climate of the early Eocene leading to a weak polar amplification. Considering dark soil, our results change. Forests cools stronger in the early Eocene climate than in the current climate because the lapse-rate and water-vapour feedback is stronger in the early Eocene climate while cloud feedbacks and cloud masking are equally strong in both climates. The different temperature change by forest in both climates highlights the state-dependency of vegetation's impact on climate.

\section{Introduction}

During the early Eocene (about 54 to 52 million years ago), climate was much warmer than today. Tropical temperatures were 5 to $6 \mathrm{~K}$ higher (Pearson et al., 2007), and polar temperatures were above the freezing point during most time of the year leading to almost ice-free poles (Hutchison, 1982; Markwick, 1994; Ivany et al., 2006; Zachos et al., 1992). The major forcing for the warm climate was a higher atmospheric $\mathrm{CO}_{2}$
CPD

11, 997-1029, 2015

\section{Radiative forcing by forest and subsequent feedbacks in the early Eocene climate}

U. Port et al.

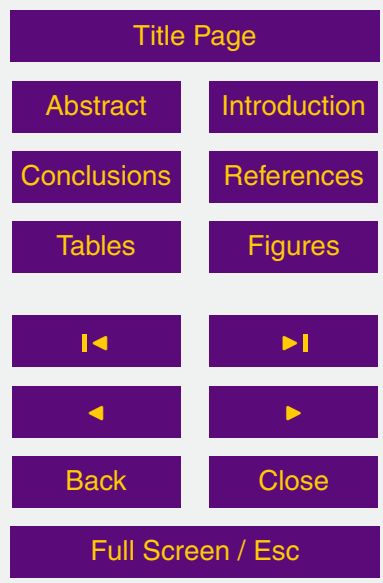

Printer-friendly Version

Interactive Discussion 
concentration than today (Heinemann et al., 2009), but also other factors may have contributed to the warm climate such as altered orbital parameters (Lawrence et al., 2003; Sewall and Sloan, 2004), an increased ocean heat transport (Barron, 1987), and different bathymetry and topography (Sewall et al., 2000). We investigate the impact of vegetation on the early Eocene climate.

Flora fossils indicate that forests dominated the vegetation cover during the early Eocene (Wolfe, 1985). Forest affects climate by taking up $\mathrm{CO}_{2}$ and by changing the land-atmosphere fluxes (heat, moisture, momentum, and energy). The latter is called the biogeophysical effect of forest. For present-day climate, the biogeophysical effect 10 of forest is well understood. In the high latitudes, forest tends to increase temperature by masking the bright snow cover and, thereby, reducing surface albedo (Bonan, 1992, 2008; Betts and Ball, 1997). The warming is amplified by the sea ice-albedo feedback (Brovkin et al., 1999, 2009; Claussen et al., 2001; Fraedrich et al., 2005). In the tropics, forest tends to reduce temperature by enhancing latent heat flux and increasing cloud 15 cover (Claussen et al., 2001; Bala et al., 2007; Bathiany et al., 2010). Considering the warm early Eocene climate, we assume that the biogeophysical effect changes. We test this hypothesis using the Max Planck Institute for Meteorology Earth System Model (MPI-ESM).

We simulate both, the early Eocene climate and the pre-industrial climate, with dense 20 forest on all continents and with bare soil on all continents, respectively. Based on the differences in temperature and radiative flux between the respective "forest world" and the respective "desert world", we derive the radiative forcing by forests and the subsequent climate feedbacks. We expect that the radiative forcing by forest depends on the soil albedo. To isolate the impact of soil albedo on the radiative forcing by forest, we simulate the desert world two times. In a first case, we assume a homogeneous soil albedo of 0.1 , which is approximately the albedo of volcanic rocks and granite bedrock (Warner, 2004). In this case, soil and forest have similarly low values of albedo. In a second case, we assume a homogeneous soil albedo of 0.4 . The bright soil has a much higher albedo than the forest.

\section{CPD}

11, 997-1029, 2015

\section{Radiative forcing by forest and subsequent feedbacks in the early Eocene climate}

U. Port et al.

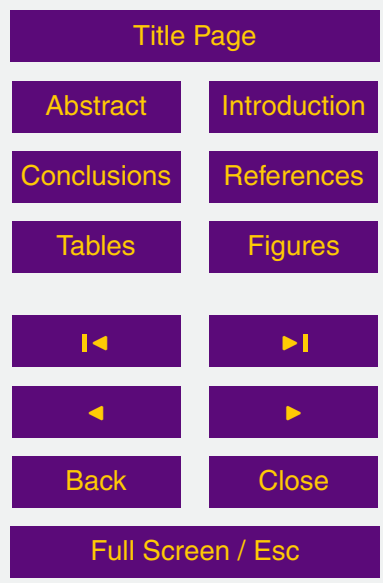

Printer-friendly Version

Interactive Discussion 
For the early Eocene climate and the pre-industrial climate, we prescribe an atmospheric $\mathrm{CO}_{2}$ concentration of 560 and $280 \mathrm{ppm}$, respectively. The respective $\mathrm{CO}_{2}$ concentration is assumed in the forest world and in the desert worlds. In other words, we neglect the $\mathrm{CO}_{2}$ uptake by forest and focus on the biogeophysical effect of forest.

\section{Model and experiments}

The MPI-ESM consists of the atmospheric general circulation model ECHAM6 (Stevens et al., 2013), the Max Planck Institute Ocean Model (MPIOM) (Jungclaus et al., 2013), the land surface scheme JSBACH (Reick et al., 2013), and the ocean biogeochemistry model HAMOCC (llyina et al., 2013). ECHAM6 and JSBACH run in a horizontal resolution of T31, which corresponds to approximately $3.75^{\circ} \times 3.75^{\circ}$. ECHAM6 considers 31 levels in the vertical up to $10 \mathrm{hPa}$. The ocean grid has a resolution of about $3^{\circ}$ and consists of 40 levels in depth.

To simulate the early Eocene climate, we use the maps of orography and bathymetry by Bice and Marotzke (2001) which Heinemann et al. (2009) interpolated from the 15 original resolution of $2^{\circ} \times 2^{\circ}$ to the model resolution of T31. The orography map lacks information on sub-grid orography. Hence, ECHAM6 cannot parametrise sub-grid interactions of atmospheric flow with orography (Stevens et al., 2013) and so we switch off the module for sub-grid orographic drag and wave generation. The distribution of continents requires to shift the regular MPIOM north pole of the ocean grid to Palaeo-Asia and the grid south pole to Palaeo-South America.

Following Heinemann et al. (2009), the atmospheric $\mathrm{CO}_{2}$ concentration is fixed to 560 ppm (Table 1), which represents the lower limit of reconstructions (Zachos et al., 2001; Beerling and Royer, 2011). Estimates of other greenhouse gases are absent for the early Eocene. Thus, we proceed as Heinemann et al. (2009) and prescribe pre-industrial values for methane and nitrous oxide in the early Eocene atmosphere (Table 1). Orbital parameters fluctuate on a shorter time scale than the early Eocene period (Laskar et al., 2004). Hence, a specific set of orbital parameters for this period

\section{CPD}

11, 997-1029, 2015

\section{Radiative forcing by forest and subsequent feedbacks in the early Eocene climate}

U. Port et al.

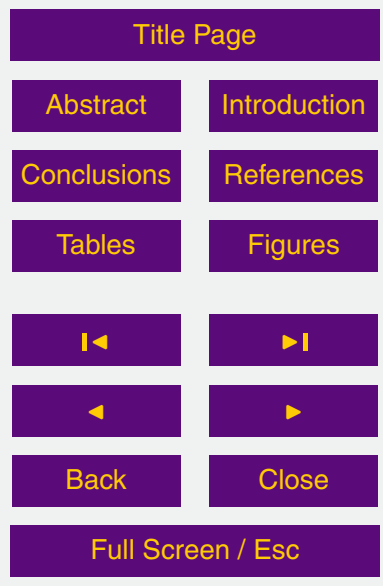

Printer-friendly Version

Interactive Discussion 
is lacking. We decide to use a pre-industrial orbit in our early Eocene simulations. This approach limits the differences between the early Eocene and the pre-industrial boundary conditions to the distribution of continents, the bathymetry, the appearance of ice sheets, and the atmospheric $\mathrm{CO}_{2}$ concentration.

$5 \quad$ We perform the same three simulations with the described early Eocene boundary conditions and with pre-industrial boundary conditions (Table 2). In the dark desert world and in the bright desert world, no vegetation occurs on all continents during the simulated 400 years. Both simulations differ concerning the assumed soil albedo. While all soils have an albedo of 0.1 in the dark desert world, all soils have an albedo of 0.4 10 in the bright desert world.

In the forest world, all ice-free continents are completely covered with forests. The vegetation cover is static and the leaf area index ( $\mathrm{LAI})$ is constant throughout the whole simulation independently of season, temperature, and water availability. We distinguish between tropical and extra-tropical trees (Fig. 1). Tropical trees have a LAI of 7 and a roughness length of $2 \mathrm{~m}$. Extra-tropical trees have a LAI of 5 and a roughness length of $1 \mathrm{~m}$. The soil albedo does not matter in the forest world which was tested by simulating the forest world climate with low and high soil albedo, respectively. Both soil albedo values reveal the same climate (not shown) because trees completely mask the soil leading to a land surface albedo of approximately 0.12 in snow-free regions in the forest world.

\section{Methods}

We aim to compare the impact of forest on the early Eocene climate and on the preindustrial climate. For this purpose, we compare the forest world simulation to the desert world simulations in both climates. All simulations run for 400 years and cli-

\section{CPD}

$11,997-1029,2015$

\section{Radiative forcing by forest and subsequent feedbacks in the early Eocene climate}

U. Port et al.

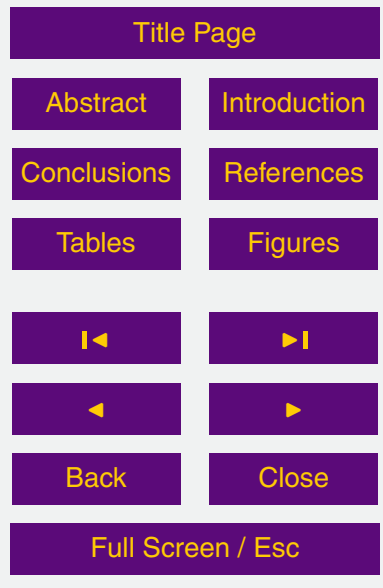

Printer-friendly Version

Interactive Discussion 
forest and the subsequent climate feedbacks using the linear regression approach by Gregory et al. (2004). This Section introduces the linear regression approach.

\subsection{Radiative forcing and climate feedbacks}

At the beginning of each simulation, we change the vegetation cover and the soil albedo 5 drastically. The modification of the land surface acts as an external forcing on the climate system and perturbs the radiation balance at the top of the atmosphere (TAO). During the simulation, the perturbation in the TOA radiation balance, $\Delta R$, changes surface temperature. Temperature changes feed back to $\Delta R$ due to internal mechanisms in the climate system. In the global mean, $\Delta R$ relates approximately linearly to the changes in surface temperature, $\Delta T$,

$\Delta R(t)=\Delta Q+\lambda \Delta T(t)$.

The instantaneous response of the radiation balance to the modification of the land surface is the radiative forcing, $\Delta Q$. The climate feedback parameter, $\lambda$, quantifies the strength of feedbacks between temperature and $\Delta R$.

The model simulations provide pairs of $\Delta R^{i}$ and $\Delta T^{i}$ for each year, $i$. Figure 2 shows the points of $\left(\Delta T^{i}, \Delta R^{i}\right)$ for the early Eocene dark desert world simulation. The initial climate is an equilibrium climate simulated with savanna on all continents. In the first year of the shown simulation, savanna is replaced by dark bare soil, and the simulated climate progressively approaches a new equilibrium. The straight line fitted to the points of $\left(\Delta T^{i}, \Delta R^{i}\right)$ reveals the parameters in Eq. (1) (Gregory et al., 2004). At the intersection of the regression line with the $\Delta R$ axis, $\Delta R$ is the radiative forcing $\Delta Q$. The slope of the regression line is the feedback parameter $\lambda . \lambda$ is negative here indicating that feedbacks counteract the perturbation in the TOA radiation balance. In other words, feedbacks stabilise climate. The new equilibrium is estimated from the intersec-

\section{CPD}

11, 997-1029, 2015

\section{Radiative forcing by forest and subsequent feedbacks in the early Eocene climate}

U. Port et al.

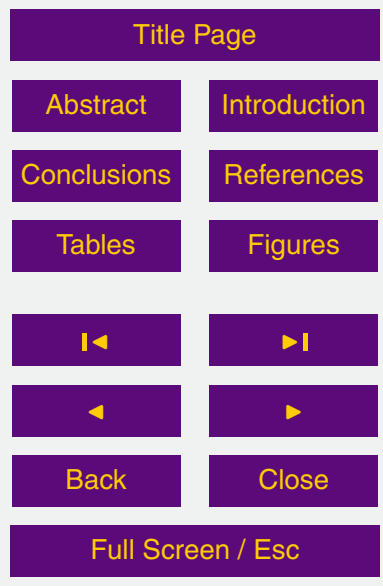

Printer-friendly Version

Interactive Discussion 
equilibrium temperature is

$\Delta T^{\mathrm{eq}}=-\frac{\Delta Q}{\lambda}$.

The linear regression approach is only valid when feedbacks are constant in time. The slope of the regression line, however, decreases with time (Gregory et al., 2004).

5 For the first decades after a perturbation, however, Gregory et al. (2004) find a constant slope. As is now customary, we consider the first 150 years of our simulation for the regression (Andrews et al., 2012).

For the forest world simulation, the linear regression approach reveals the radiative forcing and the feedbacks by afforesting savanna-like vegetation. However, we aim to 10 estimate the radiative forcing and the feedbacks from afforesting deserts on all continents. Hence, we modify the linear regression approach in the way that we combine the forest world simulation with the desert world simulations. Let $\Delta R_{\mathrm{d}}$ be the perturbation of the net ToA radiation in the case of replacing savanna with desert, and let $\Delta R_{\mathrm{f}}$ be the perturbation in the case of replacing savanna with forest. In the linear approach, 15 the difference, $\Delta R_{\mathrm{fd}}$, is the perturbation due to replacing deserts by a complete forest cover. For each year in our simulation, $i$, we receive

$\Delta R_{\mathrm{fd}}^{i}=\Delta R_{\mathrm{f}}^{i}-\Delta R_{\mathrm{d}}^{i}$

Consistently, we subtract the temperature differences of the two perturbation experiment to obtain

20 $\Delta T_{\mathrm{fd}}^{i}=\Delta T_{\mathrm{f}}^{i}-\Delta T_{\mathrm{d}}^{i}=T_{\mathrm{f}}^{i}-T_{\mathrm{d}}^{i}$.

Considering Eq. (1), the regression line to the points $\left(\Delta T_{\mathrm{fd}}, \Delta R_{\mathrm{fd}}\right)$ is

$\Delta R_{\mathrm{fd}}=\Delta Q_{\mathrm{fd}}+\lambda_{\mathrm{fd}} \Delta T_{\mathrm{fd}}$.

The radiative forcing of afforesting the desert world is expressed by $\Delta Q_{\mathrm{fd}}$. The according feedback parameter is $\lambda_{\mathrm{fd}}$. The equilibrium temperature response, $\Delta T_{\mathrm{fd}}^{\mathrm{eq}}$, is ${ }_{25}$ approximated by $\Delta R_{\mathrm{fd}}\left(\Delta T_{\mathrm{fd}}=0\right)$.

\section{Radiative forcing by forest and subsequent feedbacks in the early Eocene climate}

U. Port et al.

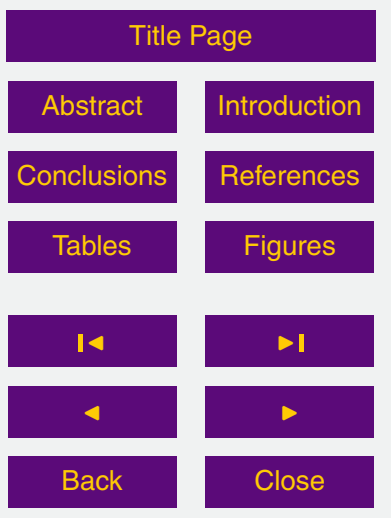

Full Screen / Esc

Printer-friendly Version

Interactive Discussion 


\subsection{Decomposition of the radiation balance}

Net perturbation in the TOA radiation balance consists of a long-wave component (LW) and a short-wave component (SW). Both components constitute of a cloud share (cl) and a clear-sky share (cs) leading to

${ }_{5} \quad \Delta R=\Delta R_{\mathrm{LWcl}}+\Delta R_{\mathrm{LWcS}}+\Delta R_{\mathrm{SWcl}}+\Delta R_{\mathrm{SWcS}}$

The clear-sky share in radiation reflects the radiation when clouds are neglected. The cloud share refers to the difference between the clear-sky radiation and the all-sky radiation (clouds are considered). We apply the linear regression technique on each of the four radiation components. The corresponding regression lines are described by

${ }_{10} \Delta R_{\mathrm{LWcl}}=\Delta Q_{\mathrm{LWcl}}+\lambda_{\mathrm{LWcl}} \Delta T$,

$\Delta R_{\mathrm{LWcS}}=\Delta Q_{\mathrm{LWcS}}+\lambda_{\mathrm{LWcS}} \Delta T$,

$\Delta R_{\mathrm{SWcl}}=\Delta Q_{\mathrm{SWcl}}+\lambda_{\mathrm{SWcl}} \Delta T$

$\Delta R_{\mathrm{sWcs}}=\Delta Q_{\mathrm{SWcs}}+\lambda_{\mathrm{sWcs}} \Delta T$.

This approach separates net radiative forcing and feedback into the single components of radiation (Andrews et al., 2012).

The long-wave clear-sky feedback parameter, $\lambda_{\mathrm{LWcs}}$, quantifies mainly to the sum of the Planck feedback, the water-vapour feedback, and the lapse rate feedback. The Planck feedback refers to the modified emission of long wave radiation when surface and troposphere change their temperature while keeping the vertical temperature gradient. For instance, a warming increases the emission of long wave radiation by the surface leading to an energy loss at the top of the atmosphere. The energy loss counteracts the initial warming and stabilises climate.

We estimate the Planck feedback parameter, $\lambda_{\mathrm{P}}$, as

$\lambda_{\mathrm{P}}=\frac{\partial R}{\partial T}=-4 \sigma \epsilon T^{3}$.

CPD

11, 997-1029, 2015

\section{Radiative forcing by forest and subsequent feedbacks in the early Eocene climate}

U. Port et al.

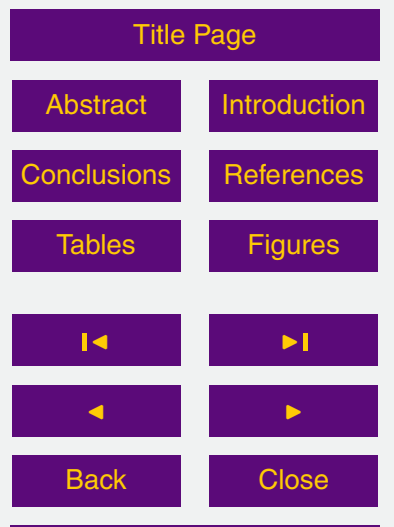

Full Screen / Esc

Printer-friendly Version

Interactive Discussion 
The term on the right hand side consists of the Stefan-Boltzmann constant, $\sigma$, the global mean surface temperature in Kelvin $[\mathrm{K}], T$, and the emissivity of the atmosphere, $\epsilon$. The emissivity describes the strength of the greenhouse effect and varies depending on the climate state. We estimate $\epsilon$ from the ratio of long-wave radiation escaping 5 at the top of the atmosphere to long-wave radiation emitted by the surface. At the beginning of the simulations, $\epsilon$ is 0.585 and 0.541 in the pre-industrial climate and in the early Eocene climate which reflects the stronger greenhouse effect in the warmer early Eocene climate. The corresponding global mean surface temperatures are 287 and $297 \mathrm{~K}$. Considering these values, Eq. (11) reveals a $\lambda_{\mathrm{P}}$ of -3.1 and $-3.3 \mathrm{Wm}^{-2} \mathrm{~K}^{-1}$ in 10 the pre-industrial climate and in the early Eocene climate, respectively. Assuming that feedbacks act linearly, we subtract $\lambda_{\mathrm{P}}$ from $\lambda_{\mathrm{LWCl}}$. The remaining feedback parameter is mainly the lapse-rate and water-vapour feedback which we name $\lambda_{\mathrm{WV}+\mathrm{LR}}$.

We quantify the uncertainty of forcings and feedbacks in terms of the $95 \%$ confidence interval which we assess using bootstrapping. We randomly select 150 pairs of differences in temperature and TOA radiative flux out of the first 150 years of our simulation. Each pair of our simulation can be selected several times. We repeat the resampling 10000 times. From each time, we estimate the feedbacks and forcings and sort the resulting 10000 values. Truncating the upper and lower $2.5 \%$ provides the $95 \%$ confidence interval.

\section{Results}

Based on the regression approach, we estimate radiative forcing of forestation and climate feedbacks. First, we compare the forest world to the bright desert world and discuss differences in radiative forcing and climate feedbacks between the early Eocene climate and the pre-industrial climate. Second, we compare the forest world to the dark desert world. In this case, forest and soil have about the same albedo which cancels the albedo effect of forest in snow-free regions. We relate the differences in radiative

\section{CPD}

11, 997-1029, 2015

\section{Radiative forcing by forest and subsequent feedbacks in the early Eocene climate}

U. Port et al.

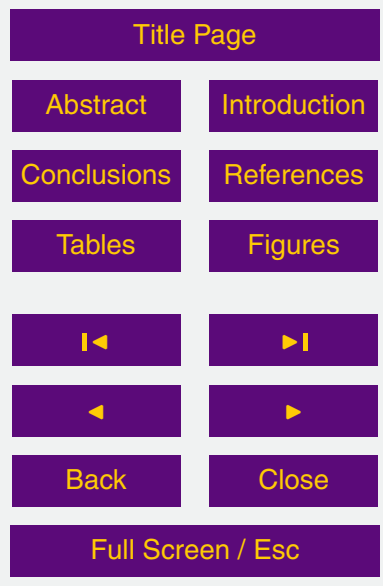

Printer-friendly Version

Interactive Discussion 
forcing and climate feedbacks between the two climate states to the differences we find in the bright-soil case.

\subsection{Forestation of a bright desert world}

Relative to the bright desert world, the forest world is 4.3 and $5.7 \mathrm{~K}$ warmer at the

of the early Eocene simulations and at the end of the pre-industrial simulations, respectively (Table 3 ). The warming results from a positive radiative forcing by trees which is 5.8 and $5.2 \mathrm{~W} \mathrm{~m}^{-2}$ in the early Eocene climate and in the pre-industrial climate. The forcings do not differ significantly at the $95 \%$ level as the confidence interval in Fig. 3 illustrates.

10 The largest component in net radiative forcing is the short-wave clear-sky radiative forcing, $\Delta Q_{\mathrm{SWcS}}$, which amounts to some $15 \mathrm{~W} \mathrm{~m}^{-2}$ in both climate states (Fig. 4). The major mechanism leading to $Q_{\mathrm{SWcs}}$ is the surface albedo reduction by forest. To evaluate the surface albedo reduction, we analyse the difference in the land surface albedo between the forest world and the bright desert world in the first year of the simulations. In the first year, mainly the contrasting vegetation cover alters surface albedo because the climate response to the radiative forcing is still weak leading to negligible changes in snow cover and sea-ice cover. In the global mean, the land surface albedo is 0.26 lower in the forest world than in the bright desert world in the early Eocene climate. In the pre-industrial climate, the land surface albedo decreases by 0.28 due to forest. The strong albedo changes in both climate states are consistent with the strength of $\Delta Q_{\text {SWcs }}$.

The second pronounced component in radiative forcing is the short-wave cloud radiative effect, $\Delta Q_{\mathrm{SWcl}}$ which amounts to -8.6 and $-11.6 \mathrm{Wm}^{-2}$ in the early Eocene climate and in the pre-industrial climate, respectively (Fig. 4). $\Delta Q_{\text {sWcl }}$ composes of the cloud 25 adjustment on one hand and the masking effect by clouds on the other hand. In our simulations, cloud adjustment refers to an increased cloud cover due to forests leading to a higher planetary albedo and a negative radiative forcing. This effect is especially strong over land, where forests strongly reduce surface albedo and the increased cloud
CPD

11, 997-1029, 2015

\section{Radiative forcing by forest and subsequent feedbacks in the early Eocene climate}

U. Port et al.

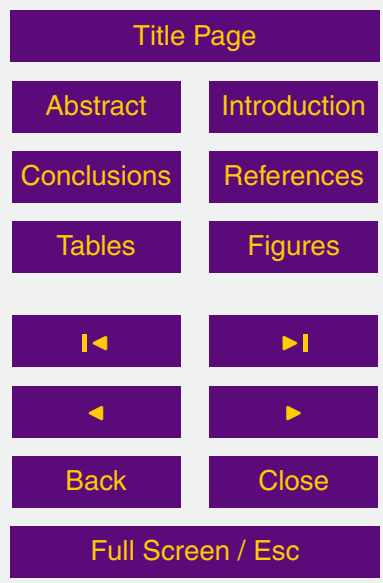

Printer-friendly Version

Interactive Discussion 
cover compensates the surface albedo reduction. Figure 5 illustrates the compensation of surface albedo reduction. Shown are the difference in planetary albedo and in cloud cover between the first year of the forest world simulation and the first year of the desert world simulation. In general, planetary albedo over land decreases due to forests, but 5 in the tropics, cloud cover increases leading to a weak decrease in planetary albedo.

The cloud masking effect is an artefact which results from separating full-sky radiation into the clear-sky component and the cloud component. In case a dense cloud cover occurs in the forest world and in the desert world, full-sky short-wave radiative forcing will be weak. Clear-sky radiation, however, will be strongly positive due to the 10 lower surface albedo in the forest world than in the desert world. Deriving the cloud forcing from the weak full-sky radiative forcing and the strongly positive clear-sky radiation reveals a strongly negative cloud radiative forcing even though cloud cover did not change. Our approach do not allow to disentangle cloud adjustment and cloud masking. Nevertheless, we assume that a considerable part of the $\Delta Q_{\mathrm{SWcl}}$ results from the 5 cloud masking effect.

Feedbacks stabilise the early Eocene climate stronger than the pre-industrial climate as the steeper slope of the regression line in Fig. 3 illustrates. Stronger stabilising feedbacks lead to a smaller equilibrium temperature response in the early Eocene climate and to a smaller temperature difference between the bright desert world and the forest world at the end of the simulations (Table 3). This result is surprising because Caballero and Huber (2013) finds that the same forcing causes a similarly strong net feedback for the warm early Palaeogene climate (about 65 to 35 million years ago) as for present-day climate.

We analyse the single components of the net feedback to identify the reason for 25 the different strength in net feedback in both climate states. The short-wave clear-sky feedback parameter, $\lambda_{\mathrm{SW} \text { cs }}$, is significantly smaller in the early Eocene climate than in the pre-industrial climate (Fig. 6). This feedback mainly refers to changes in the sea-ice cover and snow cover together with the short-wave contribution of the watervapour feedback. We expect that the ice-albedo feedback is weak in the early Eocene
CPD

11, 997-1029, 2015

\section{Radiative forcing by forest and subsequent feedbacks in the early Eocene climate}

U. Port et al.

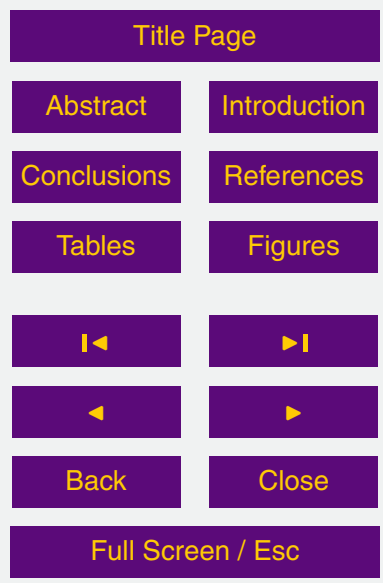

Printer-friendly Version

Interactive Discussion 
climate because permanent sea-ice is absent and snow occurs only seasonally. The small $\lambda_{\text {swcs }}$ agrees with this expectations. Also zonal mean temperature differences between the forest world and the desert world indicate a weak ice-albedo feedback as forests warm the northern high latitudes much less in the early Eocene climate than in 5 the pre-industrial climate (Fig. 7).

$\lambda_{\mathrm{WV}+\mathrm{LR}}$ largely quantifies the sum of the negative lapse-rate feedback and the positive water-vapour feedback. This feedback parameter is larger in the early Eocene climate than in the pre-industrial climate indicating either a weaker lapse-rate feedback, a stronger water-vapour feedback, or both. This result agrees with Meraner et al. 10 (2013) who suggest that the water-vapour feedback becomes stronger with warming.

Largest differences in the feedback parameters appear in the short-wave cloud feedback parameter, $\lambda_{\mathrm{SWcl}}$, which is $-0.8 \mathrm{Wm}^{-2} \mathrm{~K}^{-1}$ in the early Eocene climate and $0.1 \mathrm{Wm}^{-2} \mathrm{~K}^{-1}$ in the pre-industrial climate. Even considering the large uncertainty in the estimate, $\lambda_{\text {sWcl }}$ differs significantly in both climates. The differences in $\lambda_{\text {sWcl }}$ indi15 cate that the cloud albedo feedback is stronger and of opposite sign in the early Eocene climate than in the pre-industrial climate. $\lambda_{\mathrm{sWcl}}$, however, also includes masking effects of clouds which weakens the result on the climate-dependent cloud albedo feedback.

To identify the reason for the different $\lambda_{\mathrm{s} w_{c l}}$ in both climates, we separate the difference in the short-wave cloud radiative flux between the forest world and the bright 20 desert world, $\Delta R_{\text {SWcl }}$, into $\Delta R_{\text {SWcl }}$ above the oceans and above the continents (similar to Andrews et al., 2012). Over land, the $\lambda_{\mathrm{SWcl}}$ is nearly of the same strength in both climate states as the slope of the regression lines in Fig. 8a illustrates. Over the oceans, $\lambda_{\mathrm{SWcl}}$ is positive in the pre-industrial climate and negative in the early Eocene climate (Fig. 8b). The different sign in $\lambda_{\mathrm{sWcl}}$ indicates a different structure in cloud cover 25 changes with changes in sea-surface temperature in both climates.

The regression line in Fig. $8 \mathrm{~b}$ considers the first 150 years of the simulations but do not represent the last 250 years. Consistently with previous studies (Senior and Mitchell, 2000), this behaviour indicates a time-dependent cloud feedback which is not captured by the linear regression approach.

\section{CPD}

11, 997-1029, 2015

\section{Radiative forcing by forest and subsequent feedbacks in the early Eocene climate}

U. Port et al.

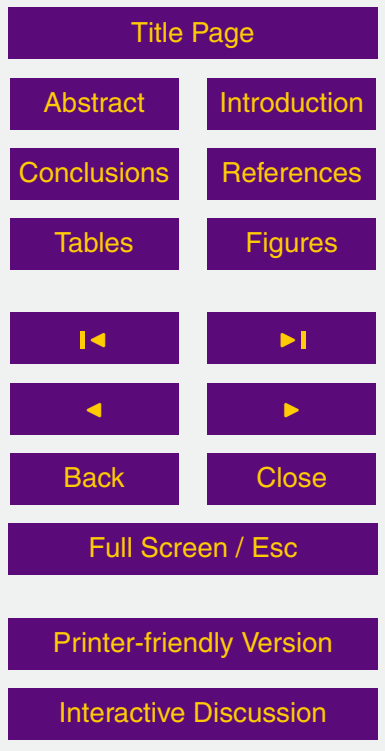




\subsection{Forestation of a dark desert world}

We showed above that forest changes temperature by lowering surface albedo and enhancing cloud cover. To isolate these two effects, we now set the soil albedo in the desert world to 0.1 which is about the albedo of forest. In other words, the albedo effect of forest is weak in snow-free regions. Relative to the dark desert world, forests reduce temperature by 4.2 and $3.0 \mathrm{~K}$ until the end of the early Eocene simulations and until the end of the pre-industrial simulations, respectively (Table 4). The cooling results from a negative radiative forcing of about $3 \mathrm{Wm}^{-2}$ in both climate states (Fig. 9).

The main contributor to the net radiative forcing is $\Delta Q_{\mathrm{SWcl}}$ (Fig. 10) which composes 10 of the cloud adjustment and the cloud masking effect. Above, we argue that cloud adjustment by forest is strong when the soil albedo is high in the desert world. In this case, forest reduces surface albedo and an increased cloud cover compensates the reduction in surface albedo (Sect. 4.1). Now, we consider a low soil albedo which is close to the albedo of forest. Hence, surface albedo changes by forest are weak leading to a weak compensation effect by an increased cloud cover. Presumably, the weak compensation effect leads to a weaker cloud adjustment than in the bright-soil case which might explain the smaller $\Delta Q_{\mathrm{SWcl}}$.

In contrast to the bright-soil case, net feedback is equally strong in the early Eocene climate as in the pre-industrial climate (Table 4). The separation into the single compo20 nents reveals that $\lambda_{\mathrm{LR}+\mathrm{VW}}$ is larger in the early Eocene climate than in the pre-industrial climate, while $\lambda_{S W_{c S}}$ is smaller. Even though the differences in $\lambda_{\mathrm{LR}+\mathrm{VW}}$ and $\lambda_{\mathrm{SW} S \mathrm{c}}$ compensate on the global scale, they are relevant on the regional scale. The larger $\lambda_{\mathrm{LR}}+\mathrm{VW}$ in the early Eocene climate indicates a stronger lapse-rate and water-vapour feedback which amplifies the cooling by forests on a global scale. The smaller $\lambda_{\text {swcs }}$ likely indi25 cates a weaker sea-ice albedo feedback which leads to a weaker polar amplification of the cooling by forest than in the pre-industrial climate.

\section{CPD}

11, 997-1029, 2015

\section{Radiative forcing by forest and subsequent feedbacks in the early Eocene climate}

U. Port et al.

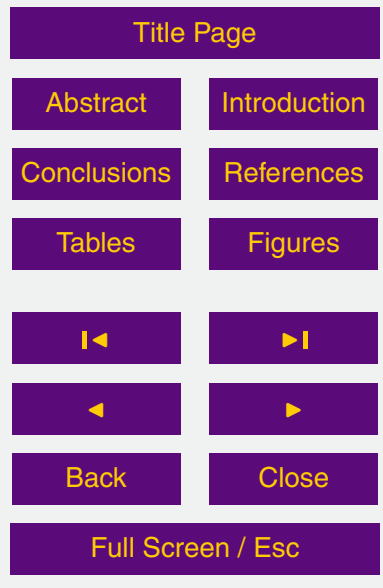

Printer-friendly Version

Interactive Discussion 


\section{Conclusions}

Our results underline that the radiative forcing by changes in vegetation cover and the feedbacks in the climate system depend on the climate state. In the current interglacial climate, forest exerts a positive radiative forcing when soil has a much higher albedo 5 than forest. The major effect is the surface albedo reduction by forest, which is partly offset by a negative cloud adjustment and masking effect. The positive net radiative forcing results in a warming and induces climate feedbacks: The lapse-rate and watervapour feedback enhances warming on global scale; and the sea-ice albedo feedback amplifies warming in the northern high latitudes.

In the nearly ice-free, warm climate of the early Eocene, forests exert a similar radiative forcing, but climate feedbacks differ considerably. The sea-ice albedo feedback is weaker in the early Eocene climate than in current climate leading to a weaker warming in the northern high latitudes. The positive lapse-rate and water-vapour feedback is stronger than in current climate. Negative cloud-related feedbacks, however, are also stronger and outweigh the stronger positive lapse-rate and water-vapour feedback. In the sum, climate feedbacks stabilise the early Eocene climate stronger than the current climate.

Assuming that soils have an albedo close to the albedo of forest, the major radiative forcing is the cloud adjustment and masking effect which is equally strong in the early 20 Eocene climate as in the pre-industrial climate. The resulting cooling, however, differs in both climates because feedbacks are differently strong. Like in the bright soil case, the positive lapse-rate and water-vapour feedback is stronger in the early Eocene climate, but this time cloud feedbacks and masking effects are of similar strenght in both climates. Hence, the net feedback stabilise the early Eocene climate less leading to 25 a stronger cooling than in the current climate. Polar amplification is still weak in the early Eocene climate due to weak sea-ice related feedbacks.

In our study, plant functional types are considered to be the same for early Eocene climate and for pre-industrial climate. We assume that this simplification will affect the

\section{CPD}

$11,997-1029,2015$

\section{Radiative forcing by forest and subsequent feedbacks in the early Eocene climate}

U. Port et al.

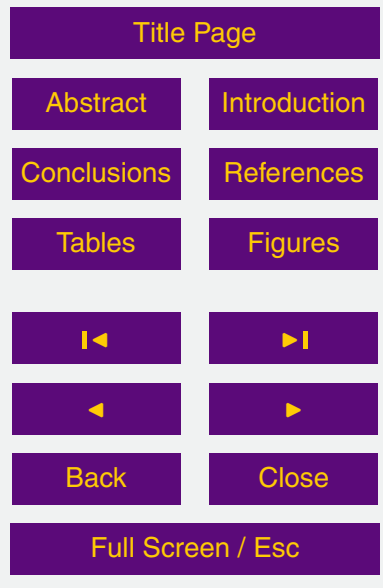

Printer-friendly Version

Interactive Discussion 
results of our study, at least in the qualitative sense, only little. We prescribe extreme land cover differences between completely forested and completely deserted continents. This difference is likely to cause much stronger effects than the difference in the physiology between current forests and early Eocene forests.

$5 \quad$ As climate has ever been changing through Earth's history, it is to be assumed that the impact of vegetation on climate is likely to change. Hence, attempts to infer potential changes in the future from processes that occurred in the past are challenging. Studies of past climates, however, help to understand the dynamics of the climate system which is a prerequisite for application of models to explore potential future changes.

10 Acknowledgements. We are grateful for comments and help by Bjoern Stevens and Thorsten Mauritsen. Further, we thank Veronika Gayler and Helmuth Haak for technical support. The anonymous reviewer improved the clarity of this paper. This work used computational recources by Deutsches Klima Rechenzentrum (DKRZ) and was supported by the Max Planck Gesellschaft (MPG).

The article processing charges for this open-access publication

have been covered by the Max Planck Society.

\section{References}

Andrews, T., Gregory, J., Webb, M., and Taylor, K.: Forcing, feedbacks and climate sensitivity in CMIP5 coupled atmosphere-ocean climate models, Geophys. Res. Lett., 39, doi:10.1029/2012GL051607, available at: http://tinyurl.sfx.mpg.de/t8j2, 2012. 1003, 1004, 1008

Bala, G., Caldeira, K., Wickett, M., Phillips, T. J., and Lobell, D. B.: Combined climate and carbon-cycle effects of large-scale deforestation, P. Natl. Acad. Sci. USA, 104, 6550-6555, 2007. 999

Barron, E. J.: Eocene equator-to-pole surface ocean temperatures: a significant climate problem?, Paleoceanography, 2, 729-739, 1987. 999

\section{CPD}

11, 997-1029, 2015

\section{Radiative forcing by forest and subsequent feedbacks in the early Eocene climate}

U. Port et al.

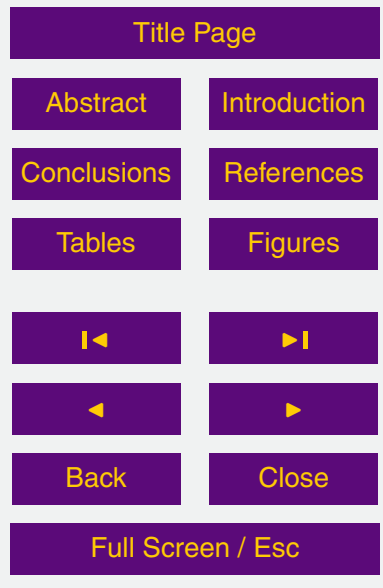

Printer-friendly Version

Interactive Discussion 
Bathiany, S., Claussen, M., Brovkin, V., Raddatz, T., and Gayler, V.: Combined biogeophysical and biogeochemical effects of large-scale forest cover changes in the MPI earth system model, Biogeosciences, 7, 1383-1399, doi:10.5194/bg-7-1383-2010, 2010. 999

Beerling, D. and Royer, D.: Convergent Cenozoic $\mathrm{CO}_{2}$ history, Nat. Geosci., 4, 418-420, doi:10.1038/ngeo1186, available at: http://tinyurl.sfx.mpg.de/t5fm, 2011. 1000

Betts, A. K. and Ball, J. H.: Albedo over the boreal forest, J. Geophys. Res.-Atmos., 102, 2890128909, doi:10.1029/96JD03876, 1997. 999

Bice, K. L. and Marotzke, J.: Numerical evidence against reversed thermohaline circulation in the warm Paleocene/Eocene ocean, J. Geophys. Res., 106, 11529-11542, 2001. 1000, 1015

Bonan, G. B.: Effects of boreal forest vegetation on global climate, Nature, 359, 716-718, 1992. 999

Bonan, G. B.: Forests and climate change: forcings, feedbacks, and the climate benefits of forests, Science, 320, 1444-1449, 2008. 999

Brovkin, Ganopolski, A., Claussen, M., Kubatzki, C., and Petoukhov, V.: Modelling climate response to historical land cover change, Global Ecol. Biogeogr., 8, 509-517, doi:10.1046/j.1365-2699.1999.00169.x, available at: http://tinyurl.sfx.mpg.de/tyey, 1999. 999

Brovkin, V., Raddatz, T., and Reick, C. H.: Global biogeophysical interactions between forest and climate, Geophys. Res. Lett., 36, L07405, doi:10.1029/2009GL037543, 2009. 999

Caballero, R. and Huber, M.: State-dependent climate sensitivity in past warm climates and its implications for future climate projections, P. Natl. Acad. Sci. USA, 110, 14162-14167, doi:10.1073/pnas.1303365110, available at: http://tinyurl.sfx.mpg.de/u3k4, 2013. 1007

Claussen, M., Brovkin, V., and Ganopolski, A.: Biogeophysical versus biogeochemical feedbacks of large-scale land cover change, Geophys. Res. Lett., 28, 1011-1014, 2001. 999

Fraedrich, K., Jansen, H., Kirk, E., and Lunkeit, F.: The Planet Simulator: green planet and desert world, Meteorol. Z., 14, 305-314, doi:10.1127/0941-2948/2005/0044, available at: http://tinyurl.sfx.mpg.de/tczv, 2005. 999

Gregory, J., Ingram, W., Palmer, M., Jones, G., and Stott, P.: A new method for diagnosing radiative forcing and climate sensitivity, Geophys. Res. Lett., 31, L03205, doi:10.1029/2003GL018747, available at: http://tinyurl.sfx.mpg.de/tcyk, 2004. 1002, 1003

Heinemann, M., Jungclaus, J. H., and Marotzke, J.: Warm Paleocene/Eocene climate as simulated in ECHAM5/MPI-OM, Clim. Past, 5, 785-802, doi:10.5194/cp-5-785-2009, 2009. 999, 1000

\section{CPD}

11, 997-1029, 2015

\section{Radiative forcing by forest and subsequent feedbacks in the early Eocene climate}

U. Port et al.

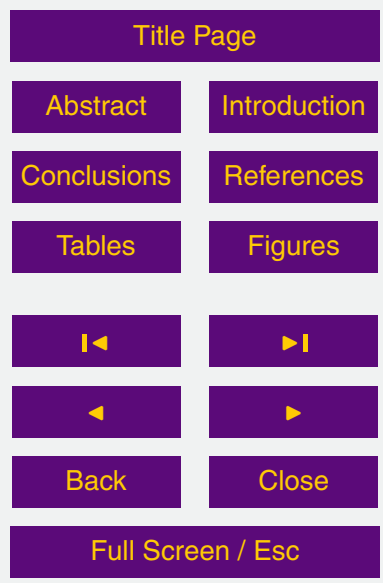

Printer-friendly Version

Interactive Discussion 
Hutchison, J.: Turtle, crocodilian, and champsosaur diversity changes in the Cenozoic of the north-central region of western United States, Palaeogeogr. Palaeocl., 37, 149-164, doi:10.1016/0031-0182(82)90037-2, available at: http://www.sciencedirect.com/ science/article/pii/0031018282900372, 1982. 998

5 Ilyina, T., Six, K. D., Segschneider, J., Maier-Reimer, E., Li, H., and Nunez-Riboni, I.: Global ocean biogeochemistry model HAMOCC: model architecture and performance as component of the MPI-Earth System Model in different CMIP5 experimental realizations., J. Adv. Model. Earth Syst., 5, 287-315, doi:10.1029/2012MS000178, 2013. 1000

Ivany, L., Simaeys, S. V., Domack, E., and Samson, S.: Evidence for an earliest Oligocene ice sheet on the Antarctic Peninsula, Geology, 34, 377-380, doi:10.1130/G22383.1, available at: http://tinyurl.sfx.mpg.de/ty1q, 2006. 998

Jungclaus, J. H., Fischer, N., Haak, H., Lohmann, K., Marotzke, J., Matei, D., Mikolajewicz, U., Notz, D., and von Storch, J. S.: Characteristics of the ocean simulations in the Max Planck Institute Ocean Model (MPIOM) the ocean component of the MPI-Earth system model, J. Adv. Model. Earth Syst., 5, 422-446, doi:10.1002/jame.20023, 2013. 1000

Laskar, J., Robutel, P., Joutel, F., Gastineau, M., and Correia, A. C. M.: A long-term numerical solution for the insolation quantities of the Earth, Astron. Astrophys., 428, 261-285, 2004. 1000

Lawrence, K. T., Sloan, L. C., and Sewall, J. O.: Terrestrial climatic response to precessional orbital forcing in the Eocene, Geol. S. Am. S., 369, 65-77, available at: http://books.google.

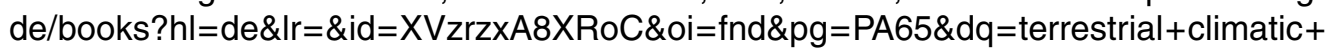
response+to+precessional\&ots=HFNIKyQg9J\&sig=BRbxYK9-DkTcbn-frmWLYEkHs7I\#v= onepage \& $q=$ terrestrialclimaticresponseto20precessional\&f=false, 2003. 999

Markwick, P.: Equability, continentality, and tertiary climate - the crocodilian perspective, Geol25 ogy, 22, 613-616, doi:10.1130/0091-7613(1994)022<0613:ECATCT>2.3.CO;2, 1994. 998

Meraner, K., Mauritsen, T., and Voigt, A.: Robust increase in equilibrium climate sensitivity under global warming, Geophys. Res. Lett., 40, 5944-5948, doi:10.1002/2013GL058118, 2013. 1008

Pearson, P., van Dongen, B., Nicholas, C., Pancost, R., and Schouten, S.: Stable warm tropical climate through the Eocene Epoch, Geology, 35, 211-214, 2007. 998

Reick, C. H., Raddatz, T., Brovkin, V., and Gayler, V.: Representation of natural and anthropogenic land cover change in MPI-ESM, J. Adv. Model. Earth Syst., 5, 459-482, doi:10.1002/jame.20022, 2013. 1000
CPD

11, 997-1029, 2015

\section{Radiative forcing by forest and subsequent feedbacks in the early Eocene climate}

U. Port et al.

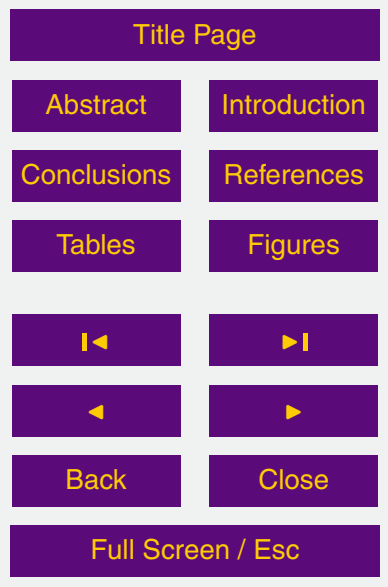

Printer-friendly Version

Interactive Discussion 
Senior, C. A. and Mitchell, J. F. B.: The time-dependence of climate sensitivity, Geophys. Res. Lett., 27, 2685-2688, doi:10.1029/2000GL011373, 2000. 1008

Sewall, J. O. and Sloan, L. C.: Less ice, less tilt, less chill: the influence of a seasonally icefree Arctic Ocean and reduced obliquity on early Paleogene climate, Geology, 32, 477-480, $5 \quad$ 2004. 999

Sewall, J. O., Sloan, L. C., Huber, M., and Wing, S.: Climate sensitivity to changes in land surface characteristics, Global Planet. Change, 26, 445-465, 2000. 999

Stevens, B., Giorgetta, M., Esch, M., Mauritsen, T., Crueger, T., Rast, S., Salzmann, M., Schmidt, H., Bader, J., Block, K., Brokopf, R., Fast, I., Kinne, S., Kornblueh, L., Lohmann, U., Pincus, R., Reichler, T., and Roeckner, E.: Atmospheric component of the MPI-M Earth System Model: ECHAM6, J. Adv. Model. Earth Syst., 5, 146-172, doi:10.1002/jame.20015, 2013. 1000

Warner, T.: Desert Meteorology, Cambridge University Press, available at: http://books.google. de/books?id=kUBxA5P7YbQC, 2004. 999

15 Wolfe, J.: Distribution of major vegetation types during the Tertiary, in: The Carbon Cycle and Atmospheric $\mathrm{CO}_{2}$ : Natural Variations Archean to Present, edited by: Sundquist, E. T. and Broecker, W. S., American Geophysical Union, Washington/DC, 357-375, 1985. 999

Zachos, J., Berza, J., and Wise, S.: Early Oligocene ice-sheet expansion on Antarctica - stable isotope and sedimentological evidence from Kerguelen Plateau southern Indian-Ocean, Geology, 20, 569-573, doi:10.1130/0091-7613(1992)020<0569:EOISEO>2.3.CO;2, available at: http://tinyurl.sfx.mpg.de/ty10, 1992. 998

Zachos, J., Pagani, M., Sloan, L., Thomas, E., and Billups, K.: Trends, rhythms, and aberrations in global climate $65 \mathrm{Ma}$ to present, Science, 292, 686-693, 2001. 1000

\section{CPD}

11, 997-1029, 2015

\section{Radiative forcing by forest and subsequent feedbacks in the early Eocene climate}

U. Port et al.

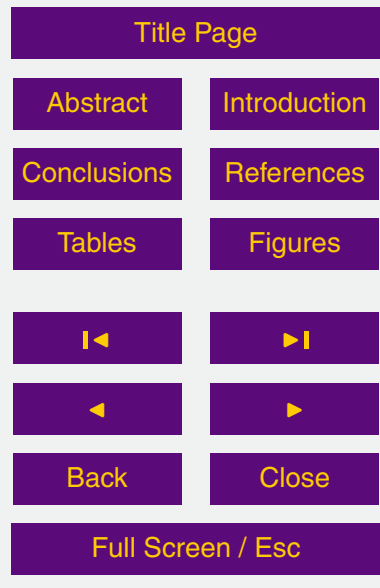

Printer-friendly Version

Interactive Discussion 
Table 1. Boundary conditions in the early Eocene climate simulations and in the pre-industrial climate simulations.

\begin{tabular}{lll}
\hline & Pre-industrial & Early Eocene \\
\hline $\mathrm{CO}_{2}$ concentration & $280 \mathrm{ppm}$ & $560 \mathrm{ppm}$ \\
Methane & $0.8 \mathrm{ppm}$ & $0.8 \mathrm{ppm}$ \\
Nitrous oxide & $0.288 \mathrm{ppm}$ & $0.288 \mathrm{ppm}$ \\
Orbit & pre-industrial & pre-industrial \\
Bathymetry and orography & present-day & Bice and Marotzke (2001) \\
Ice sheets & pre-industrial & none \\
\hline
\end{tabular}

CPD

11, 997-1029, 2015

\section{Radiative forcing by forest and subsequent feedbacks in the early Eocene climate}

U. Port et al.

\section{Title Page}

\section{Full Screen / Esc}

Printer-friendly Version

Interactive Discussion 
Table 2. Simulations performed with boundary conditions for the early Eocene climate and the pre-industrial climate. The listed vegetation cover is prescribed on all ice-free continents. The values for the land surface albedo refers to snow-free regions. In the desert world, the surface albedo equals the soil albedo. In the forest world, trees cover the soil completely and the albedo of the forest determines land surface albedo.

\begin{tabular}{lcc}
\hline & Vegetation & Land surface albedo \\
\hline Dark desert world & none & 0.1 \\
Bright desert world & none & 0.4 \\
Forest world & $100 \%$ tree cover & 0.12 \\
\hline
\end{tabular}

CPD

11, 997-1029, 2015

\section{Radiative forcing by forest and subsequent feedbacks in the early Eocene climate}

U. Port et al.

\section{Title Page}

\section{Full Screen / Esc}

Printer-friendly Version

Interactive Discussion 
Table 3. Net radiative forcing by afforesting a bright desert world in the early Eocene climate and the pre-industrial climate. Further, the net feedback parameter and the equilibrium temperature change are listed. The values are derived from the comparison of the respective forest world with the respective bright desert world. The $95 \%$ confidence interval is given. The transient temperature change refers to the temperature difference averaged over the last 30 years of the simulations.

\begin{tabular}{lcc}
\hline & Early Eocene & Pre-industrial \\
\hline Radiative forcing $\left[\mathrm{W} \mathrm{m}^{-2}\right]$ & $5.8 \pm 0.4$ & $5.2 \pm 0.5$ \\
Feedback parameter $\left[\mathrm{Wm}^{-2} \mathrm{~K}^{-1}\right]$ & $-1.4 \pm 0.1$ & $-0.7 \pm 0.1$ \\
Equilibrium temperature change $[\mathrm{K}]$ & $4.1 \pm 0.1$ & $7.3 \pm 0.7$ \\
Transient temperature change $[\mathrm{K}]$ & 4.2 & 5.7 \\
\hline
\end{tabular}

CPD

11, 997-1029, 2015

\section{Radiative forcing by forest and subsequent feedbacks in the early Eocene climate}

U. Port et al.

\section{Title Page}

\section{Abstract}

Introduction

Conclusions References

Tables

Figures

14

Full Screen / Esc

Printer-friendly Version

Interactive Discussion 


\section{CPD}

11, 997-1029, 2015

\section{Radiative forcing by forest and subsequent feedbacks in the}

Table 4. Net radiative forcing by afforesting a dark desert world in the early Eocene climate and in the pre-industrial climate. Further, the net feedback parameter and the equilibrium temperature change are listed. The values are derived from the comparison of the respective forest world with the respective dark desert world. The $95 \%$ confidence interval is given. The transient temperature change refers to the temperature difference averaged over the last 30 years of the simulations.

\begin{tabular}{lcc}
\hline & Early Eocene & Pre-industrial \\
\hline Radiative forcing $\left[\mathrm{W} \mathrm{m}^{-2}\right]$ & $-3.4 \pm 0.4$ & $-3.1 \pm 0.5$ \\
Feedback parameter $\left[\mathrm{Wm}^{-2} \mathrm{~K}^{-1}\right]$ & $-0.7 \pm 0.1$ & $-0.8 \pm 0.2$ \\
Equilibrium temperature change $[\mathrm{K}]$ & $-5.3 \pm 0.6$ & $-3.8 \pm 0.5$ \\
Transient temperature change $[\mathrm{K}]$ & -4.2 & -3.0 \\
\hline
\end{tabular}

U. Port et al.

\section{Title Page}

\section{Abstract}

Introduction

Conclusions

References

Tables

Figures

14

4

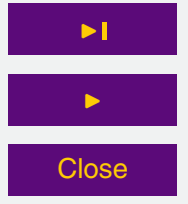

Back

Close

Full Screen / Esc

Printer-friendly Version

Interactive Discussion 

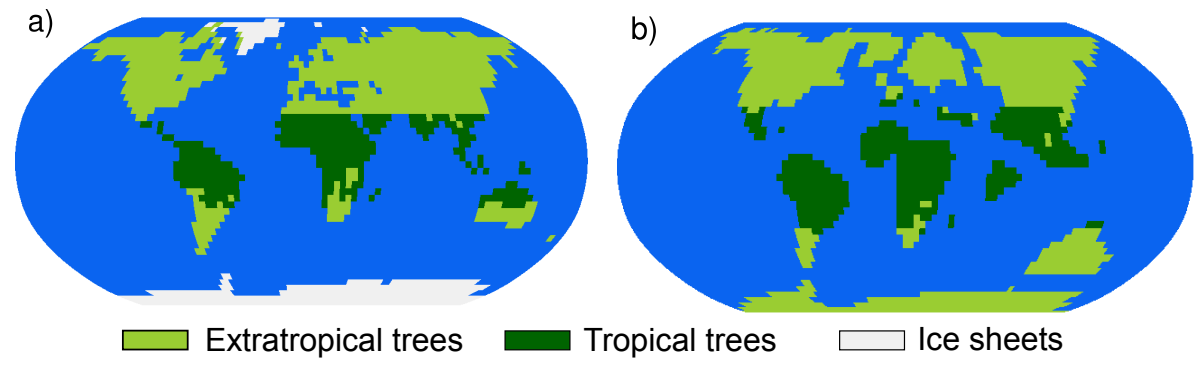

Figure 1. Vegetation cover in the forest world for the pre-industrial climate (a) and the early Eocene climate (b). Extra-tropical trees and tropical trees differ concerning their LAI and roughness length.
CPD

11, 997-1029, 2015

\section{Radiative forcing by forest and subsequent feedbacks in the early Eocene climate}

U. Port et al.

\section{Title Page}

\section{Abstract}

Introduction

Conclusions

References

Tables

Figures

14

Back

Full Screen / Esc

Printer-friendly Version

Interactive Discussion 


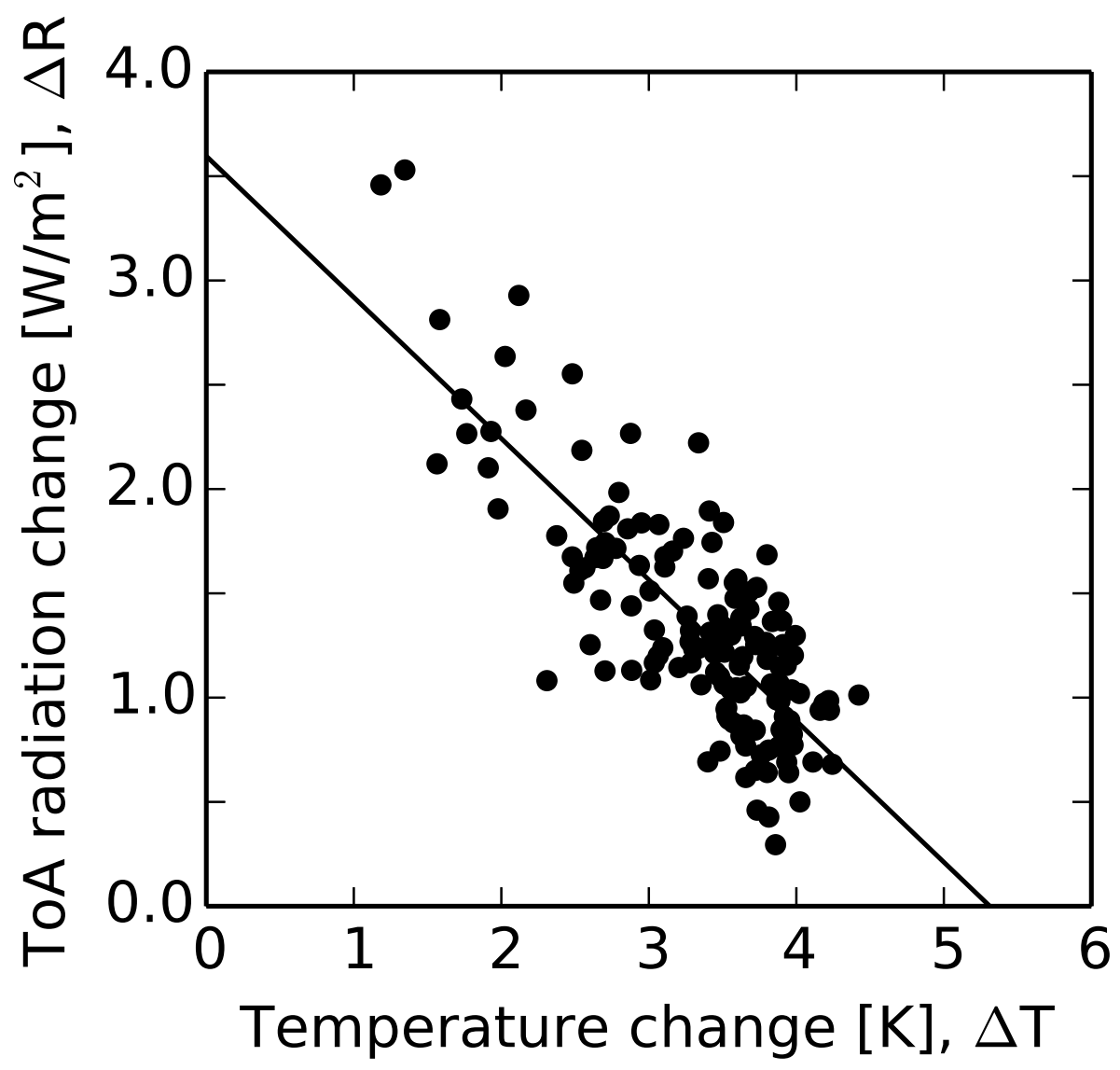

Figure 2. Evolution of radiative flux at the top of the atmosphere with temperature changes at the surface in the dark desert world of the early Eocene climate. At the beginning of the simulation, savanna-like vegetation is replaced by bare soil with an albedo of 0.1 . The first 150 simulated years are shown. The black line is the regression line fitted to the first 150 years.

\section{CPD}

11, 997-1029, 2015

Radiative forcing by forest and subsequent feedbacks in the early Eocene climate

U. Port et al.

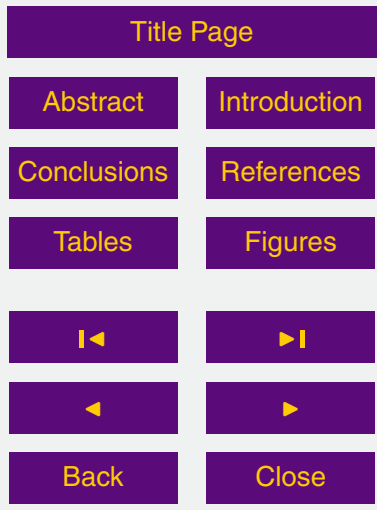

Full Screen / Esc

Printer-friendly Version

Interactive Discussion 


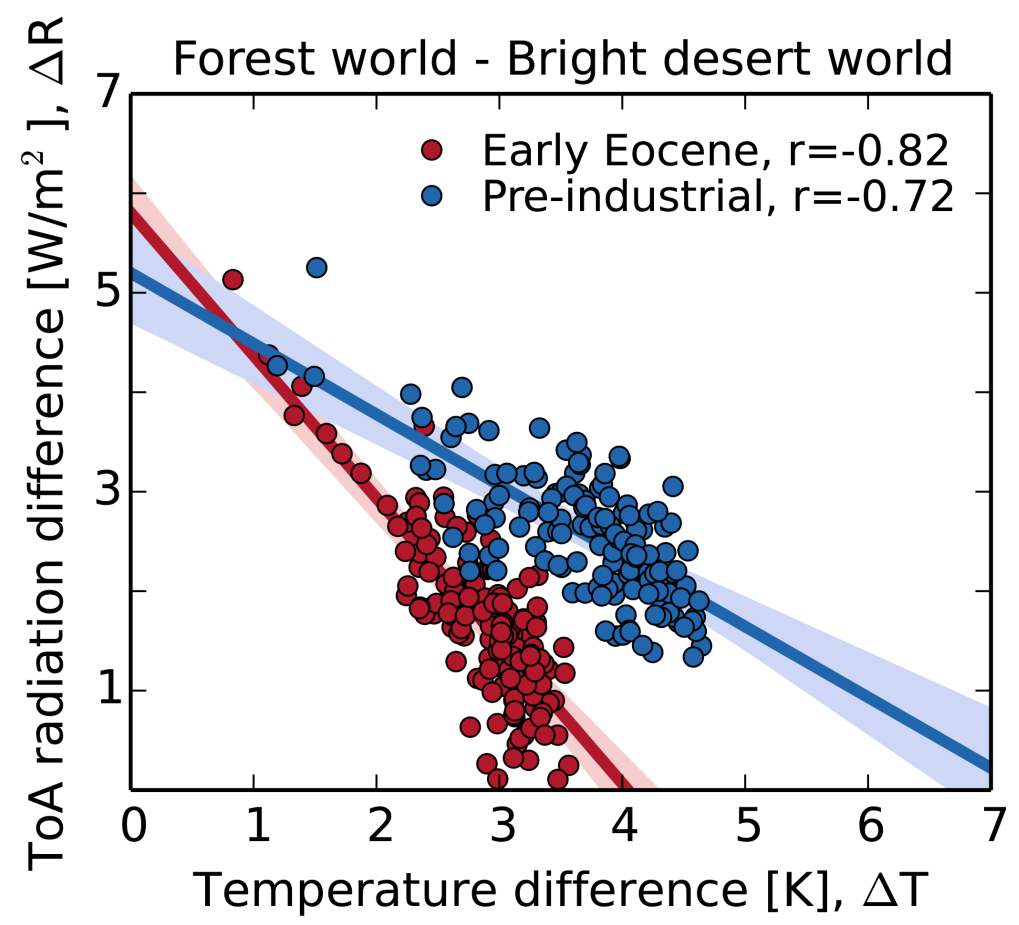

Figure 3. The evolution of differences in the TOA radiative flux between the forest world and the bright desert world with corresponding differences in near-surface temperature. Global annualmean values are considered. Red and blue points relate to the early Eocene climate and to the pre-industrial climate, respectively. Dark large points and bright small points show the first 150 and the last 250 years, respectively. The regression and the correlation coefficient, $r$, consider the first 150 years. The shaded areas refer to the $95 \%$ confidence interval for the regression lines.

\section{CPD}

11, 997-1029, 2015

\section{Radiative forcing by forest and subsequent feedbacks in the early Eocene climate}

U. Port et al.

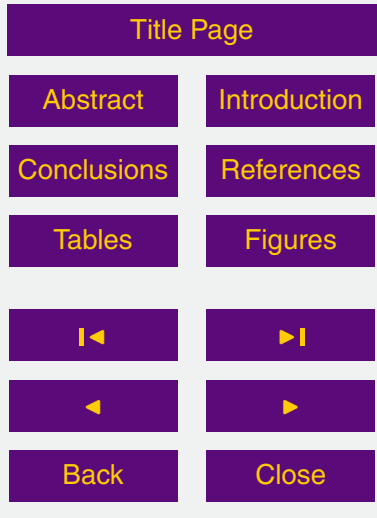

Full Screen / Esc

Printer-friendly Version

Interactive Discussion 


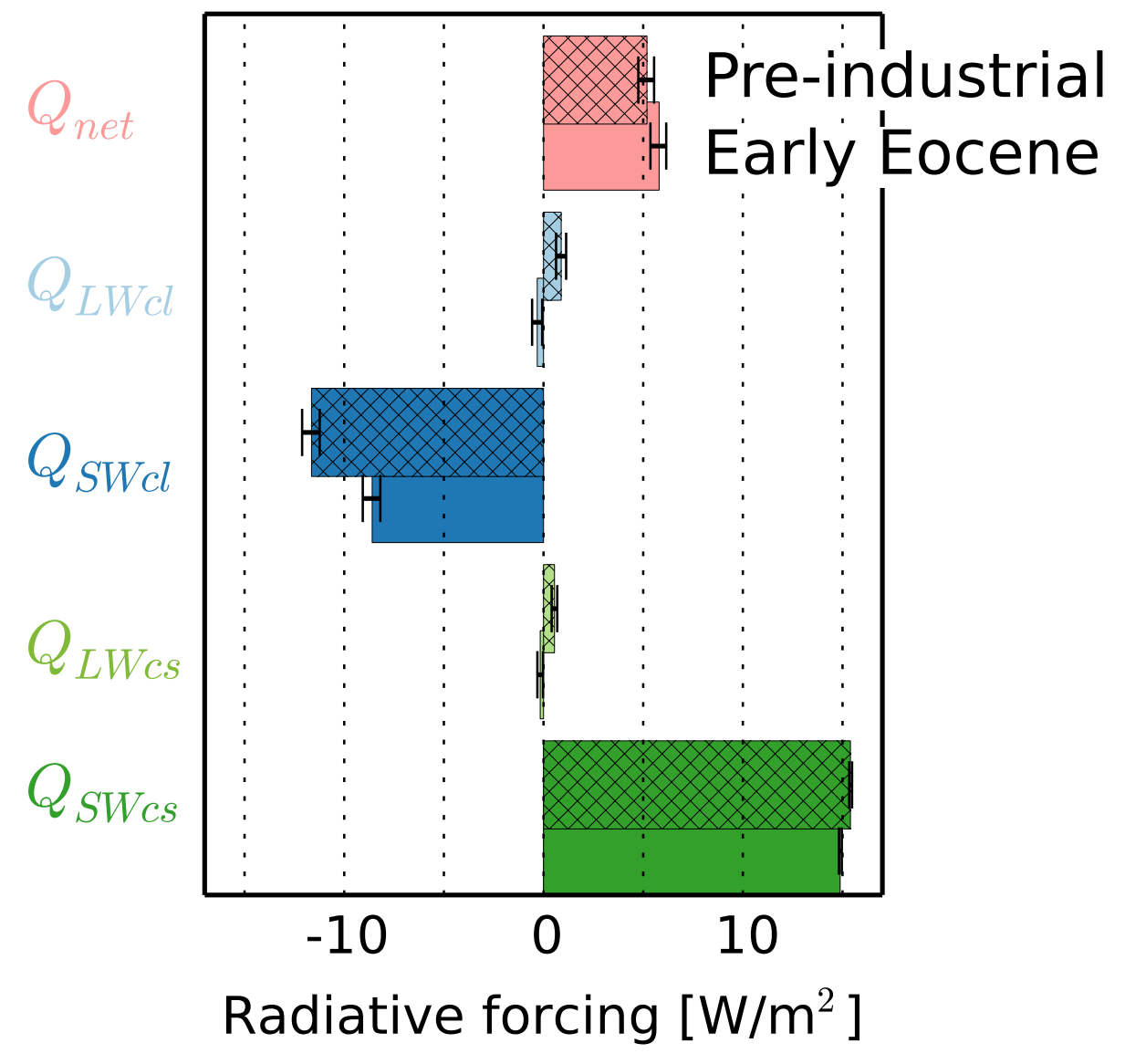

Figure 4. Net radiative forcing and its single components for the comparison of the forest world to the bright desert world. Hatched and plain bars show the radiative forcings for the preindustrial climate and the early Eocene climate, respectively. The errorbars refer to the $95 \%$ confidence interval.
CPD

11, 997-1029, 2015

\section{Radiative forcing by forest and subsequent feedbacks in the early Eocene climate}

U. Port et al.

\section{Title Page}

14

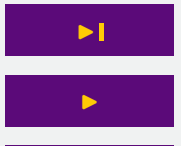

\section{Full Screen / Esc}

Printer-friendly Version

Interactive Discussion 
a)

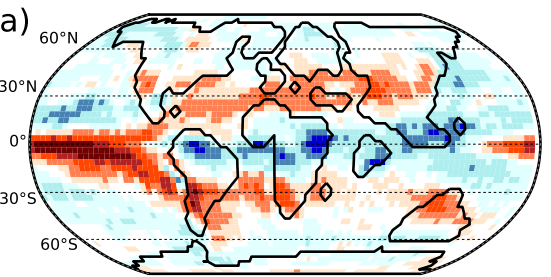

b)

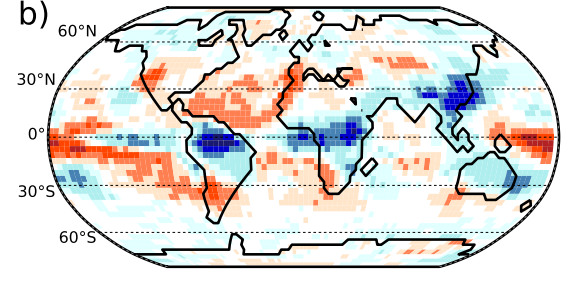

$-0.4$

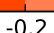

$-0.1-0.03$

$\Delta$ Cloud cover $[\backslash]$

c)

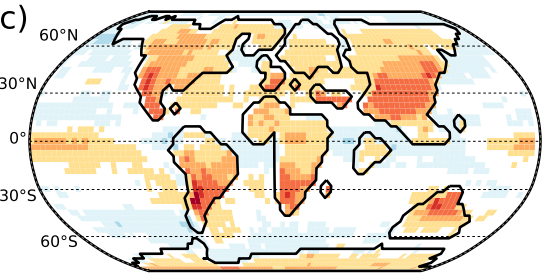

d)

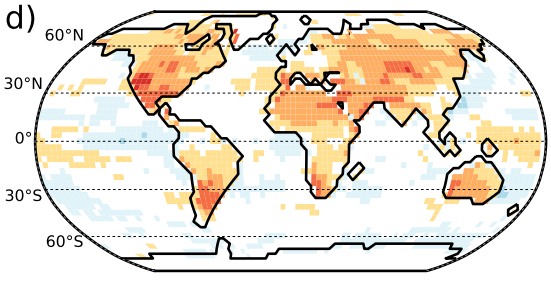

$\begin{array}{lllllll}1 & 1 & 1 & 1 & 1 & 1 & 1 \\ -0.25-0.20-0.15-0.10 & -0.03 & 0.03 & 0.10 & 0.15 & 0.20 & 0.25\end{array}$

$\Delta$ Planetary albedo [l]

Figure 5. Difference in cloud cover and planetary albedo between the forest and the bright desert world averaged over the first year of the simulations. (a) and (c) show the differences for the early Eocene climate and (b) and (d) for the pre-industrial climate.

\section{CPD}

11, 997-1029, 2015

\section{Radiative forcing by forest and subsequent \\ feedbacks in the early Eocene climate}

U. Port et al.

\section{Title Page}

\section{Abstract}

Introduction

Conclusions

References

Tables

Figures

14

4

Back

\section{Full Screen / Esc}

Printer-friendly Version

Interactive Discussion 


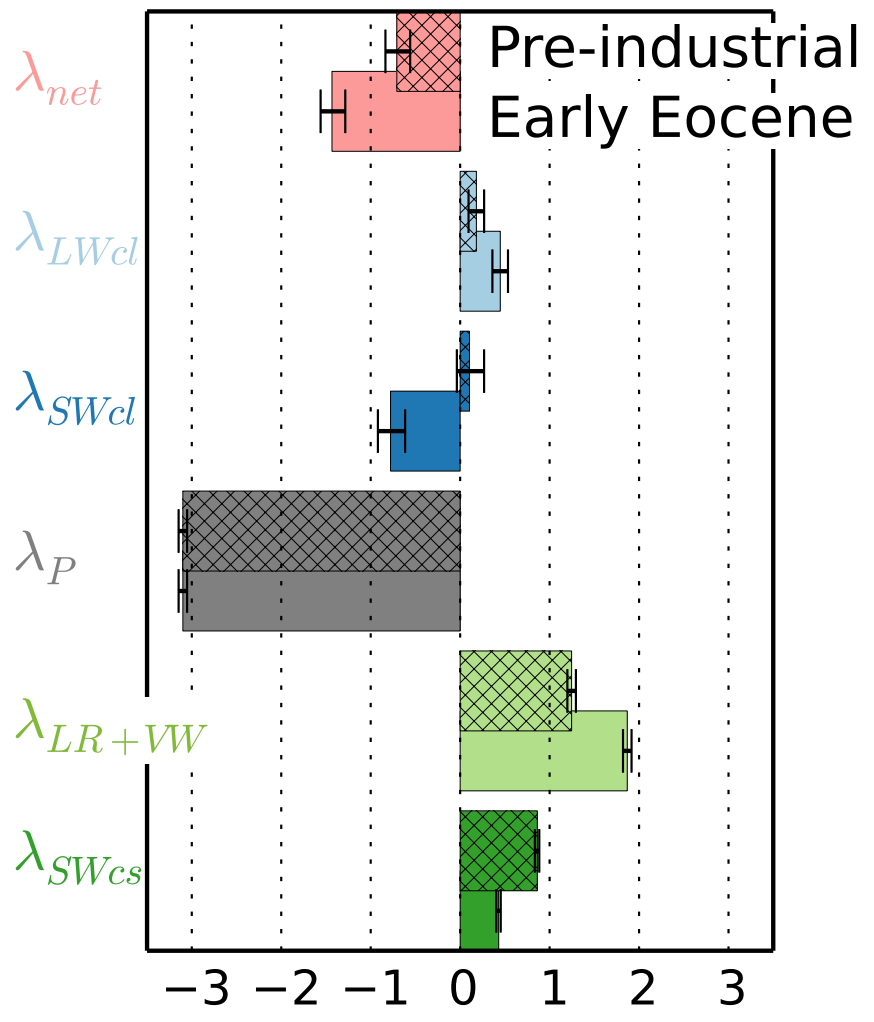

CPD

11, 997-1029, 2015

Radiative forcing by forest and subsequent feedbacks in the early Eocene climate

U. Port et al.

\section{Title Page}

14
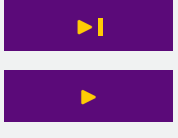

Figure 6. Net feedback parameter and its single components for the comparison of the forest world to the bright desert world. Hatched and plain bars show the feedback parameters for the pre-industrial climate and the early Eocene climate, respectively. The errorbars refer to the $95 \%$ confidence interval.

\section{Full Screen / Esc}

Printer-friendly Version

Interactive Discussion 


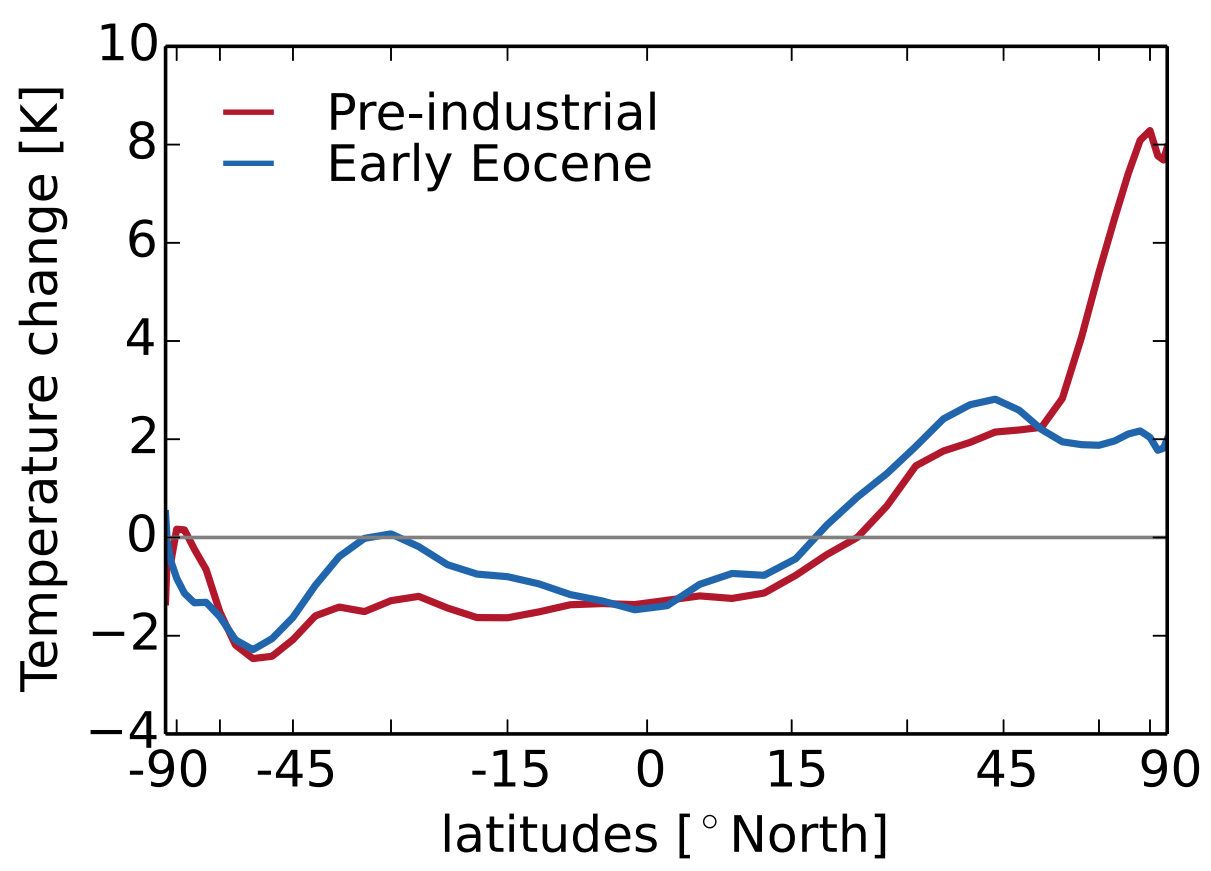

Figure 7. Anomaly of zonal mean temperature change by forest. Global mean temperature difference between the forest world and the desert world are subtracted from differences in zonal mean temperature. Red line and blue line refer to the early Eocene climate and the preindustrial climate, respectively.

\section{CPD}

11, 997-1029, 2015

\section{Radiative forcing by forest and subsequent feedbacks in the early Eocene climate}

U. Port et al.

\section{Title Page}

Abstract

Introduction

Conclusions

References

Tables

Figures

14

4

Back

Full Screen / Esc

Printer-friendly Version

Interactive Discussion 

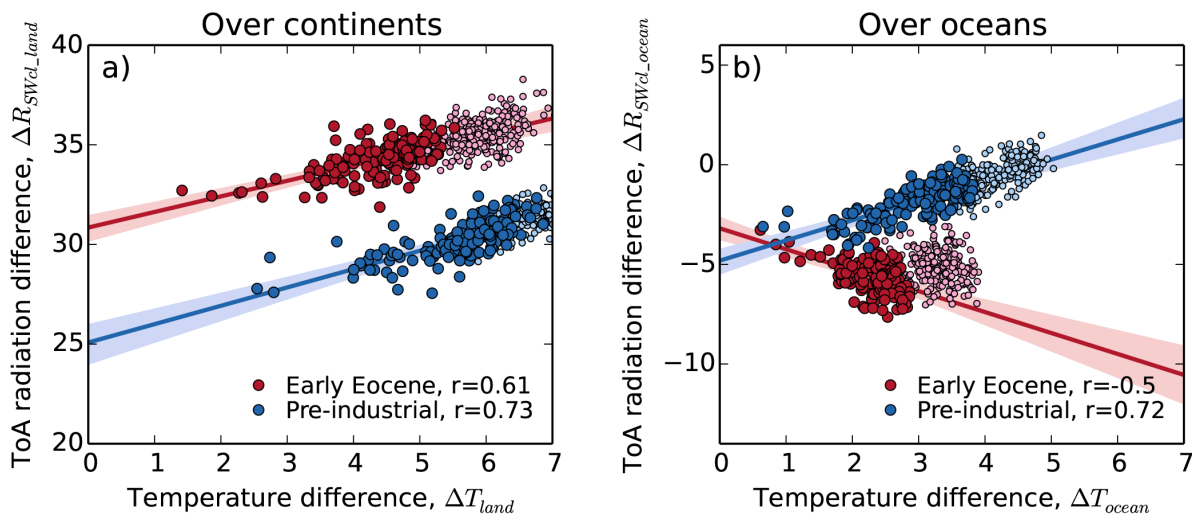

CPD

11, 997-1029, 2015

\section{Radiative forcing by forest and subsequent feedbacks in the early Eocene climate}

U. Port et al.

\section{Title Page}

Figure 8. Evolution of the difference in TOA short-wave cloud radiative flux, $R_{\mathrm{SWc}}$, with differences in near-surface temperature between the forest world and the bright desert world. The evolution of $R_{\mathrm{SWcl}}$ is separated in the evolution above the continents (a) and above the oceans (b). Global annual-mean values are considered. Red and blue points relate to the early Eocene climate and to the pre-industrial climate, respectively. Dark large points and bright small points show the first 150 and the last 250 years, respectively. The regression and the correlation coefficient, $r$, consider the first 150 years. The shaded areas refer to the $95 \%$ confidence interval for the regression lines.

Conclusions

Tables

References

14

4

Back

\section{Full Screen / Esc}

Printer-friendly Version

Interactive Discussion 


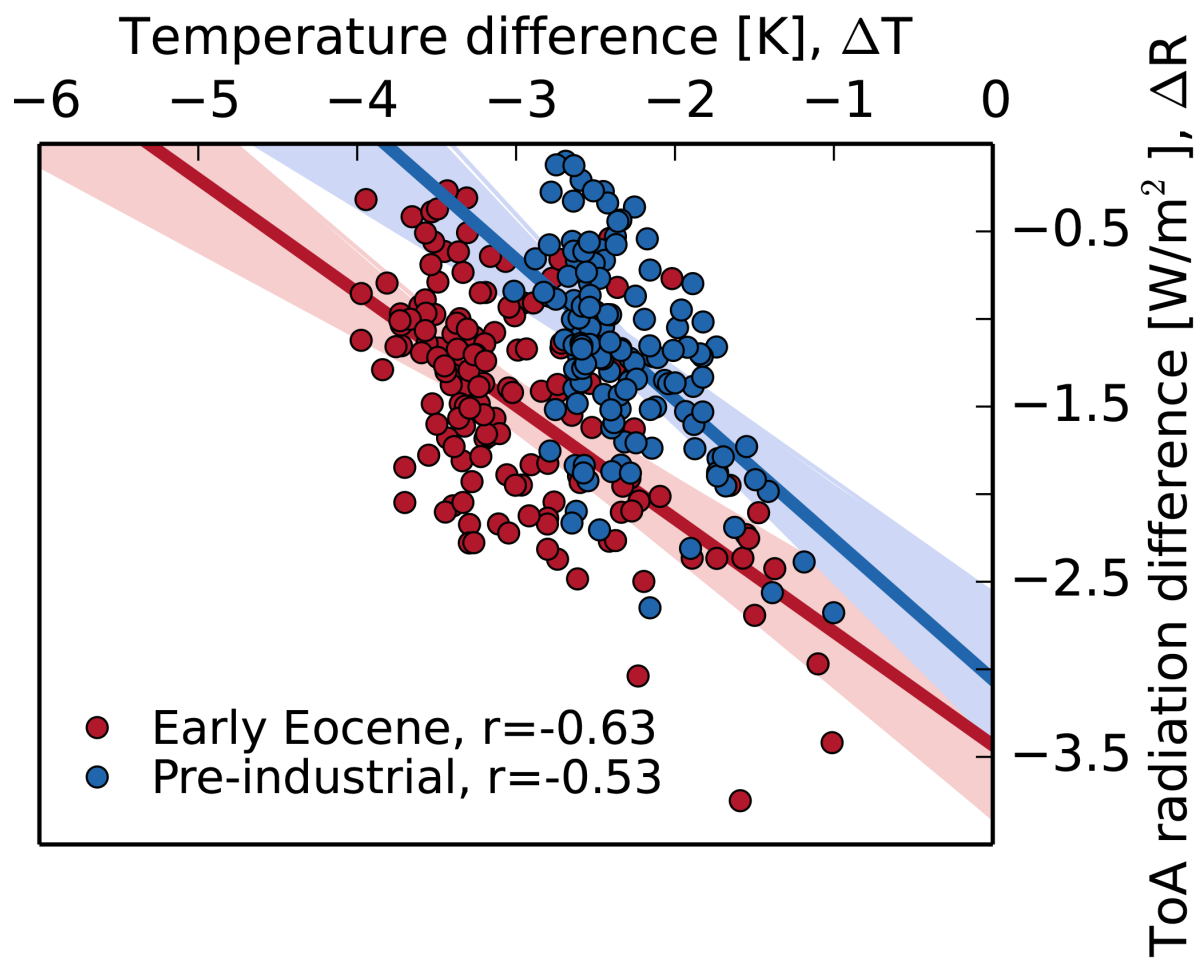

Figure 9. The evolution of differences in the TOA radiative flux between the forest world and the dark desert world with corresponding temperature differences. Global annual mean values are considered. Red and blue points relate to the early Eocene climate and to the preindustrial climate, respectively. Dark large points and bright small points show the first 150 and the last 250 years, respectively. The regression and the correlation coefficient, $r$, consider the first 150 years. The shaded areas refer to the $95 \%$ confidence interval for the regression lines.
CPD

11, 997-1029, 2015

\section{Radiative forcing by forest and subsequent \\ feedbacks in the early Eocene climate}

U. Port et al.

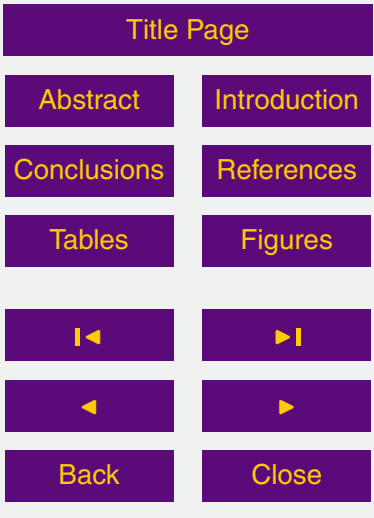

Full Screen / Esc

Printer-friendly Version

Interactive Discussion 


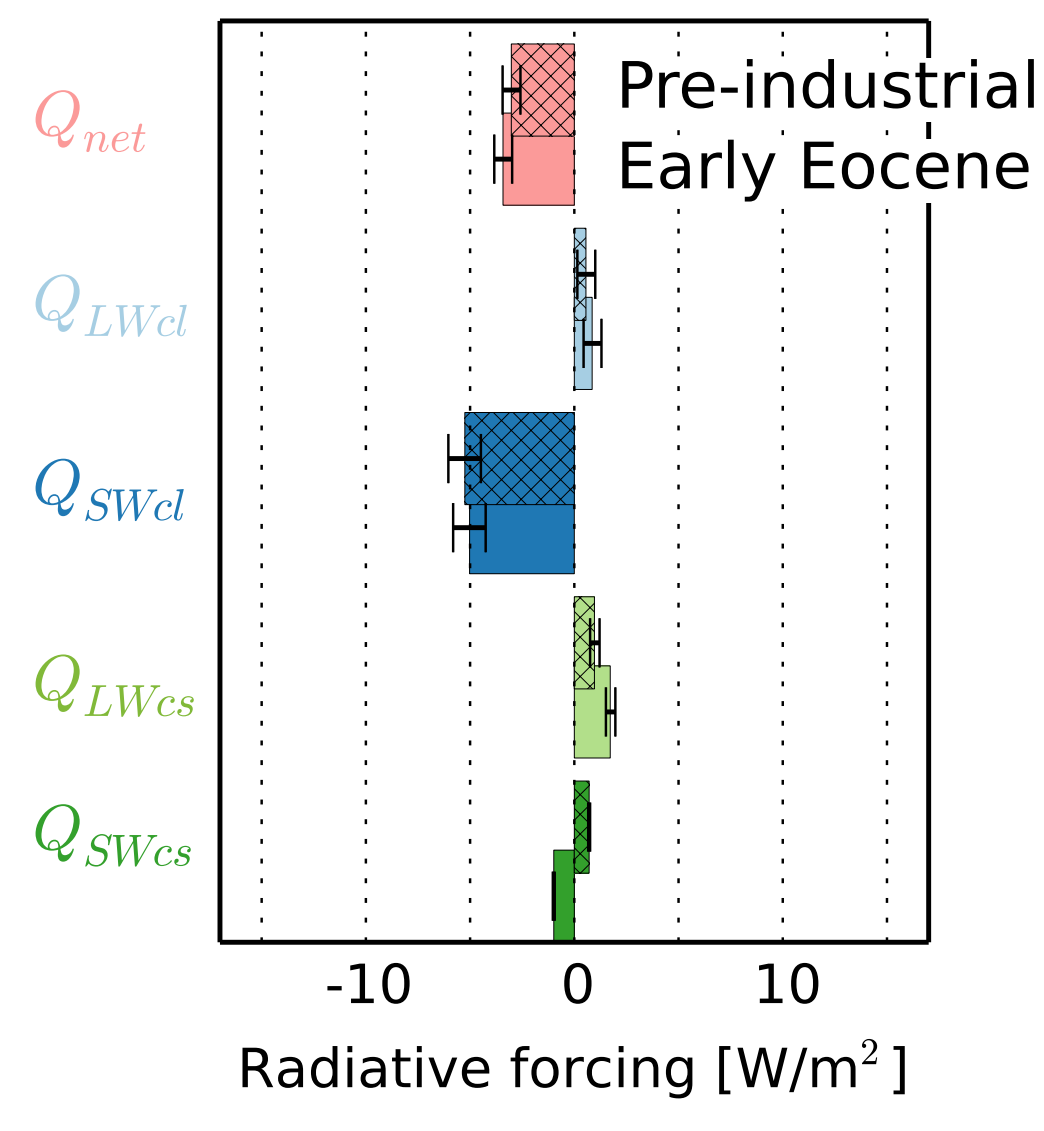

Figure 10. Net radiative forcing and its single components for the comparison of the forest world to the dark desert world. The hatched and the plain bars show the radiative forcings for the pre-industrial climate and the early Eocene climate, respectively. The errorbars refer to the $95 \%$ confidence interval.
CPD

11, 997-1029, 2015

\section{Radiative forcing by forest and subsequent feedbacks in the early Eocene climate}

U. Port et al.

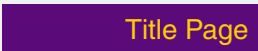

Abstract

Introduction

Conclusions

References

Tables

Figures

14

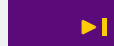

4

Back

Close

Full Screen / Esc

Printer-friendly Version

Interactive Discussion 


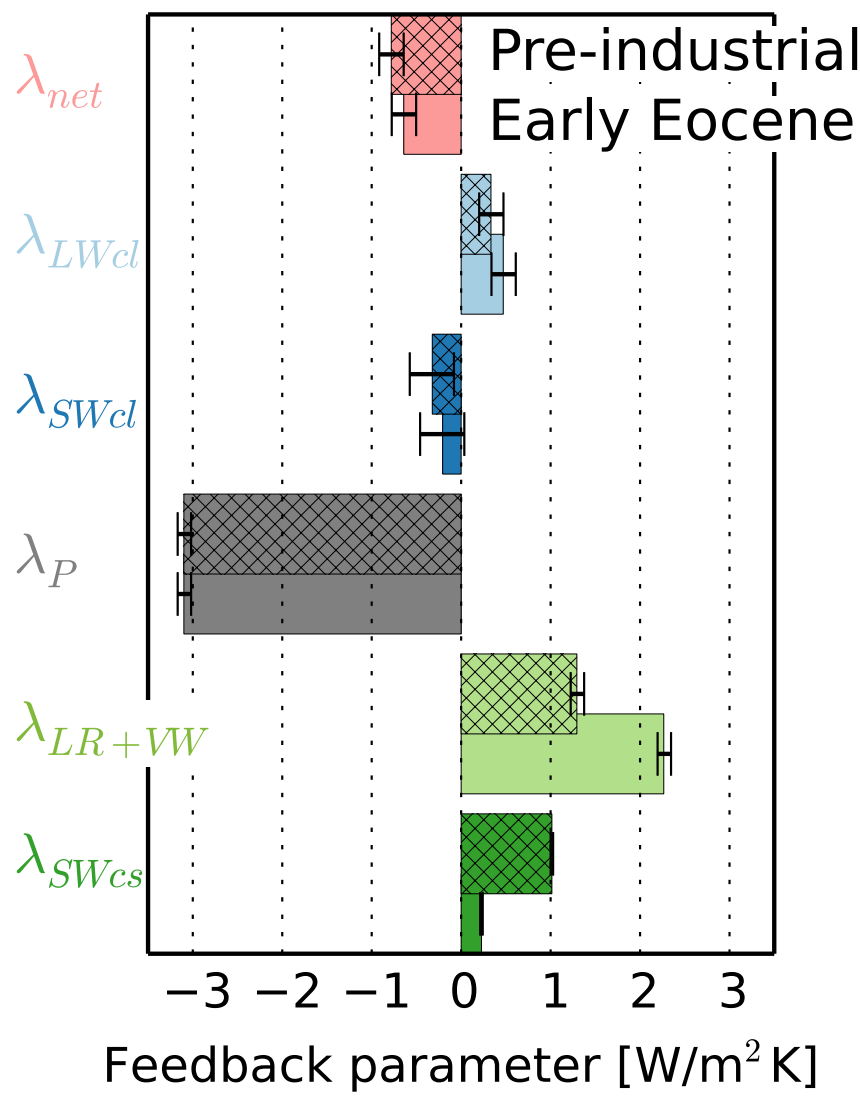

Figure 11. Net feedback parameter and its single components for the comparison of the forest world to the dark desert world. The hatched and the plain bars show the feedback parameters for the pre-industrial climate and the early Eocene climate, respectively. The errorbars refer to the $95 \%$ confidence interval.
CPD

11, 997-1029, 2015

\section{Radiative forcing by forest and subsequent feedbacks in the early Eocene climate}

U. Port et al.

\section{Title Page}

14

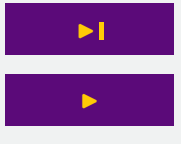

\section{Full Screen / Esc}

Printer-friendly Version

Interactive Discussion 